\title{
Letter from the Editors
}

By sheer coincidence, this issue of Itinerario has a strong emphasis on Latin America and the Hispanic world, including our interview with Sir John Elliott. We continue striving to publish an interview with a distinguished scholar in every issue. Next autumn, we hope to publish in bookform a collection of interviews that were done by Itinerario over the past two decades.

By way of an experiment, we are publishing a lengthy and lively debate that we were able to cull from the Internet. Easy as it may seem to fill some pages of a journal with such material, we can assure our readers that it has taken considerable effort to secure permission for publication from the various contributors to the debate. We welcome comments on this venture either by e-mail or by snail-mail.

Leonard Blussé \& Hans Vogel

\author{
BIBLIOTHEEK GESCHIEDENIS \\ Rijks Universiteit Leiden \\ Doelensteeg 16,2311 VLLeiden \\ Telefoon 071-527 2662
}

